\title{
Development of Mathematical Module-Problem Solving Approach to Train Student's Reflective Thinking
}

\author{
Rezki Ramdani ${ }^{1}$, Agustan Syamsuddin ${ }^{1 *}$, Sirajuddin Sirajuddin ${ }^{1}$ \\ ${ }_{1}$ Universitas Muhammadiyah Makassar, INDONESIA
}

*Corresponding Author: agustan@unismuh.ac.id

Citation: Ramdani, R., Syamsuddin, A. and Sirajuddin, S. (2019). Development of Mathematical ModuleProblem Solving Approach to Train Student's Reflective Thinking. Pedagogical Research, 4(4), em0040. https:// doi.org/10.29333/pr/5861

Published: July 23, 2019

\begin{abstract}
This research paper aims to produce a mathematical module with a problem-solving approach to train student's reflective thinking. To find out how to develop modules, there are three criteria must be fulfilled, namely validity, practicality, and effectiveness. Development of module used four stages, namely the initial situation analysis, design development, preparation of the initial product and evaluation. The module developed was assessed by 4 validators, namely 2 lecturers and 2 junior high school teachers. After that, the module was tested twice, the first one is tested on 5 students and then tested on 7 students for testing empirical validity toward the developed modules. Based on the results of the validation of the expert validator on the aspects of subject matter, performance, language and concept evaluation in the module, it can be concluded that the module developed were practical and valid with the average of assessment results validator of 3.31. While the results of the first and second stages of the trial of module, it can be concluded that the module display was interesting for students. In addition, the results of the evaluation of the trial subjects met the minimal completeness criteria so that it could be said that each of the subjects could understand the content presented in the module. From these results it was known that the module was effective. It can be seen in the results of the subject's assessment of the modules were valid and effective with the average of subject's assessment was 3.342.
\end{abstract}

Keywords: module, reflective thinking, problem-solving approach

\section{INTRODUCTION}

Mathematics learning has not given much attention to the development of high-level thinking skills such as reflective thinking skills and mathematical problem solving. In fact, these two abilities are very important, because in everyday life everyone is always faced with various problems that must be solved and demands reflective thinking to find solutions to the problems at hand. Problem solving ability is a part of the mathematics curriculum that is very important, because, in the process of learning and completion, students are able to gain experience using the knowledge and skills which already applying in problem solving.

In recent years, reflective thinking has become a very popular term in the world of education. At present reflective thinking has become the most prominent issue in various literatures, specifically in teacher professional education (Amidu, 2012; Lim, 2011). In addition, reflective thinking is a type of high-level thinking that encourages student curiosity and shows the interrelationship between learning material (Lipman, 2003).

This is in line with the demands of the 2013 curriculum of Indonesia explicitly found key words in core competencies and basic competencies such as scientific behavior (including curiosity, objectivity, honesty, thoroughness, thoroughness, diligence, caution, responsibility, openness, critical, creative, innovative and caring 
for the environment), conducting experiments and discussing, analyzing, presenting data and graphics. This confirms that reflective thinking that encourages student curiosity is a future competency that must be taught to students to answer the challenges of globalization and be able to adapt to change and respond to the demands of the 21 st century.

Furthermore, Ambrose (2004), Gelter (2003) and Koszalka (2001) stated that reflective thinking has been identified as an important component in education that provides opportunities for students to justify misconceptions by helping students think what they are doing and why they are doing that matter.

By reflective thinking, students can solve more complex problems because students' thoughts will be directed and students who think reflective the solutions solved the problem tend to be right and correct. This is consistent with the research of King and Kitchener (Koszalka, 2001) which stated that reflective thinking helps a person to solve complex problems, because reflective thinking helps one identify concepts, facts, formulas, and theories that are relevant to the solution to the problem identified. In addition, reflective thinking also involves the process of analyzing, comparing, synthesizing, clarifying, and choosing what someone is doing that shows reflection activities themselves (Henderson, 2004; Kocoglu, 2008).

A learning will not work well if it is not supported by the appropriate learning device. If learning does not go well, the expected results will not be achieved. So that in order to develop student's reflective thinking in mathematics learning, an appropriate learning tool is needed. For example, on subject matter of circumference and broad of rectangle and square so that students can practice their reflective thinking with problem solving approaches. On the other hand, the availability of quality textbooks is still very lacking. The authors of textbooks do not think much about how the book is easily understood by students. The rules of learning psychology and design theories of a textbook are not applied at all in the preparation of textbooks. As a result, students find difficulties to understand the books which they read and often they are boring.

The use of Student's Worksheets (LKS) as a companion in learning mathematics is less able to meet the needs of students to achieve optimal mathematics learning goals. For example when students need an introduction to understanding material that requires reasoning, LKS does not provide illustrations or problems in daily life. The presentation of LKS material is only a summary of material which is certainly not enough as a reference for learning mathematics, while students need material exposure that enables them to achieve learning goals. Therefore, it requires proper handling of the problem of mathematics learning by creating learning resources that can accommodate all interests and needs of students.

Learning resources are expected to meet the student's learning needs and can adjust to the speed of understanding of each student. The learning source contains at least certain mathematical material, learning activities, student worksheets and teacher guidelines to utilize these learning resources in learning. Modules are a unit of teaching programs arranged in certain forms for learning purposes.

\section{LITERATURE STUDY}

\section{Reflective Thinking}

Dewey (Fisher, 2008) stated that reflective thinking is active, persistent, and careful consideration of any belief or suppose from of knowledge in the light of the grounds that support it and the conclusion to which it tends.

From the above definition, it can be explained that reflective thinking is an active thinking process that is persistent, and carefully considers everything that is believed to be true. Schülke and Steinbring (2010) defined the reflective thinking as cognitive activity that results in changes in understanding or perspective, through a process of re-interpretation. Whereas Atkins and Murphy (1994) suggested that reflective thinking is a thought process to realize something based on experience and then interpret the experience. Based on these two definitions, reflective thinking is emphasized on interpreters based on their experience.

Agustan, Juniati and Siswono (2017) argued that reflective thinking is a mental activity to empower experience or knowledge then by considering concepts, facts and knowledge in the form of mathematical concepts, mathematical principles that are considered relevant or appropriate and believed to be correct for solving mathematical problems. Agustan (2016) further explained that the reflective thinking consists of four components, namely; (1) Formulation and synthesis of the experience that is as a process of formulating problems using experiences that already have and interweaving or linking information explicitly stated in the problem; (2) Order of experience as a process of summarizing ideas or experiences to construct a problem solving strategy for the problem at hand; (3) Evaluation of experience; as a process of evaluating experiences by considering the relevance of experience with information related to the resolution or problem solving done and (4) Testing the solutionbased selected on the experience is a process of testing a solution or conclusion that has been made in the previous stage to lead to a conclusion which is more believed to be true. 


\section{Module}

Mulyasa (2006) said that the module is an independent learning package that includes a series of learning experiences that are planned and designed systematically to help students achieve learning goals. Modules are a learning process regarding a particular unit of discussion arranged in a systematic, operational, and directed way to be used by students. While Prastowo (2012) argued that the module is a book written with the aim that students can learn independently without or with the guidance of the teacher. In another view, the module is interpreted as a set of teaching materials that are presented systematically, so that users can learn with or without a facilitator or teacher. Thus, a module must be used as a teaching material in lieu of the educator's function. If the educator has a function to explain something, then the module must be able to explain something in a language that is easily accepted by students according to their level of knowledge and age.

According to the Directorate General of PMPTK, Ministry of Education (2008), the module can be said to be good if it fulfills 5 characteristics. The first one is selfinstructional. It means that through the use of modules, students are able to learn independently and not always depend on the teacher or other parties. To fulfill the Self Instructional character, the module must meet the criteria (1) contains clearly formulated objectives, (2) contains learning material that is packaged into small units so that it facilitates complete learning, (3) contains examples and industries that support clarity the presentation of the learning method, (4) contains practice questions and assignments that allow students to respond and can measure their level of mastery, (5) contains contextual problems, (6) use simple and communicative language, (7) contains summaries of learning material, (8) contains an assessment instrument that allows the use of self assessment, (9) contains feedback on the assessment, so that its use knows the level of mastery of the material, (10) provides information about references or references that support learning materials and modules.

The second characteristics is one is self contained. It means that all learning materials from one competency unit or sub-competencies studied are contained in a module as a whole. The purpose of this concept is to provide opportunities for students to learn thoroughly and the module can contain a series of planned and systematic learning activities. The third characteristic is stand alone. Stand alone describes that the modules developed are not dependent on other media or do not have to be used together with other learning media. If the module is still in touch or still needs other media, then it cannot be said that the module is independent.

The fourth is adaftive. Adaptive explains that modules can arrange the development of science and technology, and are flexible to use, this is a module that is said to be Adaftive. In addition, an adaptive module is if the content of learning material can be used up to a certain period of time. The last is user friendly. It means that modules must be friendly to their owners. In other words the module must be easy to understand so that it makes it easier for students to understand from the contents of the modules that have been provided, so that it is not only a handbook but also as a handle and textbook that must be learned.

According to Prastowo (2012), module as one form of teaching material have the following functions. The first one is independent teaching material. The use of modules in the learning process serves to increase the ability of students to learn on their own without depending on the presence of educators. The second function is replacing educator functions. Modules as teaching materials that must be able to explain learning material well and easily understood by students according to their level of knowledge and age. While the explanatory function of something is also attached to the educator. Therefore, the use of modules can function as a substitute for educator functions.

The last one is module as an evaluation tool. By using modules, students are required to be able to measure and assess their own level of mastery of the material they have learned. As a reference material for students. Modules contain various materials that must be studied by students.

\section{Development of Module}

Mbulu and Suhartono (2004) said that teaching material or subject matter is the content of learning contained in books written by instructors or other writers for the benefit of learning. Furthermore, it is mentioned that teaching materials designed and developed based on good learning principles will be able to help students in the learning process, help teachers to reduce material presentation time and increase teacher guidance time for students, assist schools in completing curriculum and achieving learning goals with available time.

Furthermore, Mbulu and Suhartono suggested that the steps in developing the module consist of four stages. The first steps is analysis of the initial situation. The initial situation analysis aims to identify the subject matter being developed and the students' initial abilities must have. The second is the development of the module design. It determines basic competencies that are in accordance with the subject matter in developing the module and what activities are contained in the module. The third step is the preparation of the initial product of the module. It is to etermine the material in the module based on the basic competencies that have been taken and compile the contents and completeness of the module. The last step is module assessment. The module assessment means assessing the validity and practicality of modules that have been developed in several mathematicians then tested on students to find out their effectiveness. 


\section{METHOD}

The method used in the development of the module is Research and Development $(\mathrm{R} \& \mathrm{D})$. It is used to produce certain products and test the effectiveness of these products. This module is said to be good / feasible if it meets the quality aspects, among others: (1) validity, (2) practicality and (3) effectiveness. The types of products produced in this development are teaching materials in the form of modules. Module development uses four stages, namely the initial situation analysis, design development, preparation of the initial product and product evaluation (Mbulu and Suhartono, 2004). This product will be tested for its feasibility. To test whether or not it is feasible, initially this module will be validated first to see its validity and practicality when used as teaching material. After the module is said to be valid, the module is given to students to see its effectiveness.

The module developed was assessed by 4 validators, namely 2 mathematics lecturers and 2 junior high school teachers. After that, the module was tested twice, first tested on 5 students and then tested on 7 students to test the empirical validity of the modules that had been developed.

\section{RESULT AND DISCUSSION}

\section{Overview of Expert's Validation Results Related the Development of Module}

Data obtained from the results of the validation of the module carried out by 4 validators consisting of 2 lecturers majoring in mathematics education and 2 junior high school mathematics teachers. In general, the results of the expert validator's assessment of the module developed are good but there needs to be a revision of the language and symbols and images that are less representative. Symbols used by researchers are not appropriate when used in learning modules, for example the broad symbols used sometimes use $l$ and $L$.

Thus, the validator concludes that the researcher was inconsistent in writing symbols that need to be revised by the researcher. In addition, sometimes researchers made images that are not representative of the flat builds presented in the module. The size of the image made was sometimes less representative of the size because in the picture size of $10 \mathrm{~m}$ is longer than the size of $15 \mathrm{~m}$. Stages of problem solving must also describe the reflective thinking process of students in solving the problem.

In this study, data analysis related to the results of validation consisted of an analysis of the validation sheet conducted by an expert validator. By using data analysis techniques based on the data obtained, the module validity criteria are obtained based on the results of the calculation of validator's assessment criteria presented in Table 1.

Based on Table 1, it appears that the results of the calculation of each aspect of the evaluation of the module developed are in the valid category with an average of 3.31. Thus the module that has been developed does not need to be revised and it can be concluded that the development module is valid and practical to be used as teaching material. 
Table 1. Data analysis of module assessment by validators

\begin{tabular}{|c|c|c|c|c|c|c|c|c|}
\hline No & Statement & $V_{1}$ & $V_{2}$ & $V_{3}$ & $V_{4}$ & $\sum_{i=1}^{4} V i$ & $\overline{\boldsymbol{V}}$ & Criteria \\
\hline \multicolumn{9}{|c|}{ Subject Matter Aspects in the Module } \\
\hline 1 & Suitability of module content with learning objectives & 3 & 4 & 4 & 4 & 15 & 3.75 & Valid / not revised \\
\hline 2 & $\begin{array}{l}\text { Subject matter raises aspects of the connection with the real } \\
\text { world }\end{array}$ & 3 & 3 & 4 & 4 & 14 & 3.5 & Valid / not revised \\
\hline 3 & $\begin{array}{l}\text { The concept is clarified by using the right illustrations or } \\
\text { images }\end{array}$ & 3 & 4 & 4 & 4 & 15 & 3.75 & Valid / not revised \\
\hline 4 & $\begin{array}{l}\text { The accuracy of the information on the contents of the } \\
\text { module }\end{array}$ & 3 & 3 & 3 & 4 & 13 & 3.25 & Enough valid/not revised \\
\hline 5 & Clarity of description and discussion on material & 3 & 3 & 4 & 3 & 13 & 3.25 & Enough valid/not revised \\
\hline \multicolumn{9}{|c|}{ Module Presentation Aspects } \\
\hline 6 & There is learning objectives & 3 & 3 & 4 & 4 & 14 & 3.5 & Valid / not revised \\
\hline 7 & There is time allocation to study the module & 3 & 3 & 4 & 4 & 14 & 3.5 & Valid / not revised \\
\hline 8 & The presentation emphasizes meaningfulness and benefits & 3 & 3 & 4 & 4 & 14 & 3.5 & Valid / not revised \\
\hline 9 & $\begin{array}{l}\text { A summary is provided to make it easier for students to } \\
\text { understand the material they have just learned }\end{array}$ & 4 & 3 & 4 & 4 & 15 & 3.75 & Valid / not revised \\
\hline 10 & $\begin{array}{l}\text { The presentation and writing of concepts, terms, symbols and } \\
\text { important formulas are clearly presented }\end{array}$ & 3 & 3 & 3 & 3 & 12 & 3 & Enough valid/not revised \\
\hline 11 & Display settings on the attractive module & 3 & 3 & 3 & 3 & 12 & 3 & Enough valid/not revised \\
\hline \multicolumn{9}{|c|}{ Language Aspects Used in Modules } \\
\hline 12 & The sentence used is easy to understand & 3 & 3 & 3 & 3 & 12 & 3 & Enough valid/not revised \\
\hline 13 & $\begin{array}{l}\text { The structure of the sentence in accordance with the student's } \\
\text { level of proficiency }\end{array}$ & 3 & 3 & 3 & 3 & 12 & 3 & Enough valid/not revised \\
\hline 14 & The sentence used is communicative & 3 & 3 & 3 & 3 & 12 & 3 & sed \\
\hline \multicolumn{9}{|c|}{ Concept Evaluation Aspects in the Module } \\
\hline 15 & $\begin{array}{l}\text { Accuracy of questions on formative tests and evaluation } \\
\text { questions }\end{array}$ & 3 & 3 & 3 & 3 & 12 & 3 & Enough valid/not revised \\
\hline 16 & Suitability of questions with Learning objectives & 3 & 3 & 4 & 3 & 13 & 3.25 & Enough valid/not revised \\
\hline 17 & Ease of practice questions to understand & 3 & 3 & 3 & 4 & \multirow{2}{*}{\multicolumn{3}{|c|}{$\frac{3.25 \quad E_{1}}{\mathbf{5 6 . 2 5}}$}} \\
\hline \multicolumn{6}{|c|}{ Total } & & & \\
\hline \multicolumn{6}{|c|}{ Mean } & 13.24 & 3.31 & Valid / not revised \\
\hline
\end{tabular}

Table 2. The results of subjects' evaluation of the module in the first stage

\begin{tabular}{ccc}
\hline No. & Subject & Score \\
\hline 1 & $S_{1}$ & 92 \\
\hline 2 & $S_{2}$ & 73 \\
\hline 3 & $S_{3}$ & 77 \\
\hline 4 & $S_{4}$ & 93 \\
\hline 5 & $S_{5}$ & 89 \\
\hline
\end{tabular}

\section{Overview of Module Limited Test Results Related to the Development of Module}

Data in module trials are obtained from the results of questionnaires and results of student learning outcomes tests on mobile material and square and square area after studying the given module. There are two stages in testing this module. In the first stage, the module was tested on 5 students and in the second stage, the module was tested on 7 students. The full data can be seen in Table 2 and 3 which presents student test results data after studying the temporary module Table 4 presents data on student assessment of the module. Table 2 shows the results of evaluating the trial subjects related to the modules that have been developed.

The results of the subjects' evaluation in the first stage showed that the scores of each student have met the specified minimal completeness criteria (KKM), which is 70.00 . The process in solving the problem in the modules by students, there are still difficulties faced by students so that the module still has to be revised. Revisions are made to make it easier for students to work on modules and understand the modules presented to students. After the revision was carried out, then the second phase of the module was tested which was tested on 7 students. Table 3 shows the results of the subjects' evaluation of the second stage.

The results of the students' evaluation in the second stage showed that the scores of each student had met the specified minimal completeness criteria $(\mathrm{KKM})$, namely 70.00 . The process in solving the problem in the modules by students in the second group has no significant difficulties so that in the module after the second stage of the trial, there was no revision. Based on the data in Table 2 and 3. it is known that the value of the test subjects fulfills the standard of learning completeness, namely obtaining a minimum test score of 70.00 . This shows that students can understand the material in the module. 
Table 3. The results of subjects' evaluation of the module in the second stage

\begin{tabular}{ccc}
\hline No. & Subject & Score \\
\hline 1 & $S_{1}$ & 85 \\
\hline 2 & $S_{2}$ & 87 \\
\hline 3 & $S_{3}$ & 82 \\
\hline 4 & $S_{4}$ & 83 \\
\hline 5 & $S_{5}$ & 87 \\
\hline 6 & $S_{6}$ & 93 \\
\hline 7 & $S_{7}$ & 73 \\
\hline
\end{tabular}

Table 4. The results of the students' assessment toward the module

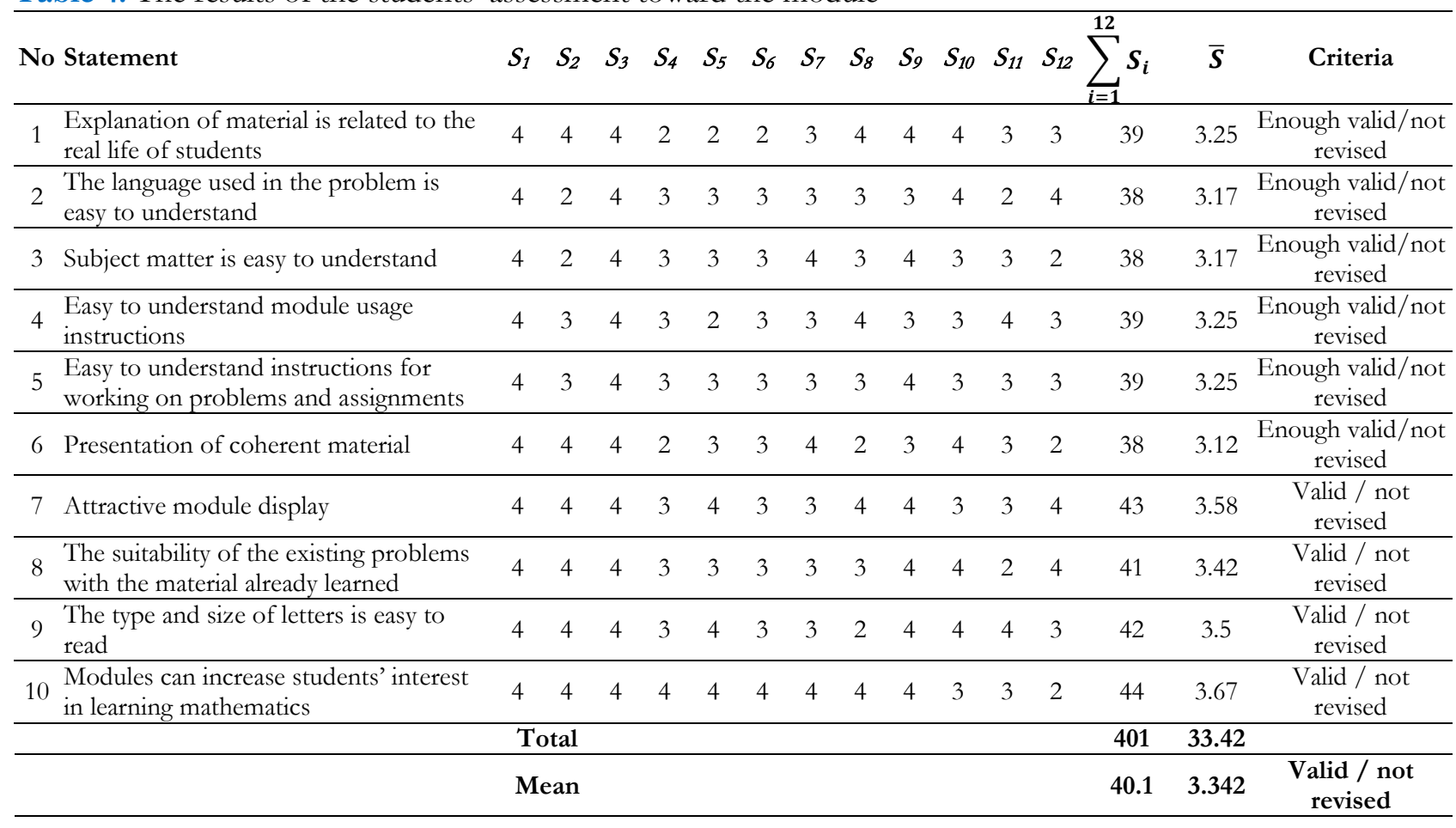

Furthermore, to support the explanation of the determination of the results of the subjects' assessment related to the subject's response to the questionnaire that has been given, the validity criteria of the module are calculated based on the results of the evaluation of 12 subjects as presented in Table 4.

Based on Table 4, the results of data analysis related to the results of evaluation tests and the results of student responses to questionnaires that have been given where students' assessment of the developed modules are in the valid category with mean 3,342. It can be concluded that this development module is effective used as teaching material.

\section{CONCLUSION}

Based on the results of the development and discussion that has been described before, some conclusions can be taken as follows. (1) Based on the results of the validation from the expert validator described earlier, all aspects of module assessment which include material or subject matter, presentation, language and concept evaluation aspects in the module can be concluded that the module developed in subject matter "circumference and area of rectangle and square" is practical and valid with the average score of the validator is 3.31. (b) Based on the results of the first and second stage trials on the subjects, it can be concluded that the display of module in the subject matter "circumference and area of rectangle and square" is attractive to students. In addition, the results of the evaluation of the subjects meets the minimal completeness criteria (KKM) that was determined so that it could be concluded that each of the test subjects could understand the material presented in the module. Module is effective used in the limited trial to two small groups. This can be seen in the results of the subjects' assessment of the module that are valid and effective with the average of subjects' judgment to 3.342. (c) Based on the exposure of the data above, it can be concluded that the development module is valid, practical, and effective. Thus the module developed can be said to be feasible if it is used as an alternative mathematics teaching material in the subject matter "circumference and area of rectangle and square". This module that has been developed meets the requirements to be used as an alternative teaching material because in this module there are standards of competence and basic competencies, 
indicators and learning objectives, material and students' learning activities, evaluation, follow-up, bibliography as references or reference material in compiling the module and the glossary to explain the important terms contained in the module.

\section{ACKNOWLEDGEMENTS}

We would like to express our deepest appreciation to all those who provided me the possibility to complete this report. A special gratitude we give to Kemenristek dikti Kemenristek Dikti who has funded this research in the scheme "Penelitian Dosen Pemula" with contract number SP DIPA-042.06.1.401516/2018, December 5, 2017.

\section{REFERENCES}

Agustan, S., Juniati, D. and Siswono, T. Y. E. (2017). Investigating and analyzing prospective teacher's reflective thinking in solving mathematical problem: A case study of female-field dependent (FD) prospective teacher. Proceeding of The International Seminar of Mathematics, Science, and Computer Science Education (MSCEIS 2016), Bandung, Indonesia, 15 October, 1848(1). https://doi.org/10.1063/1.4983956

Agustan. (2016). Kemampuan memformulasi dan mensintesis masalah aljabar calon guru matematika sebagai salah satu komponen dalam berpikir reflektif. Prosiding Seminar Nasional Universitas Cokroaminoto Palopo, 07 May, 2(1), 75-82.

Ambrose, R. (2004). Initiating change in prospective elementary school teachers' orientations to mathematics teaching by building on beliefs. Journal of Mathematics Teacher Education, 7, 1-119. https://doi.org/10.1023/B:JMTE.0000021879.74957.63

Amidu, A. R. (2012). Exploring Real Estate Students' learning approaches reflective thinking and academic performance. 48th ASC Anuual International Conference Proceedings. The Associated of Construction. UK.

Fisher. (2008). A critical thinking: an introduction. Jakarta: Erlangga.

Gelter, H. (2003). Why is reflective thinking uncommon? Journal of Reflective Practice, 4(3), 337-344. https://doi.org/10.1080/1462394032000112237

Henderson, K. (2004). Encouraging Reflective Learning: An Online Challenge. Proceedings of The 21th ASCILITE Conference, 357-364.

Kocoglu, Z., Aykel, A. and Ercetin, G. (2008). Pen/paper and electronic portofolios: an effective tool for developing reflective thinkingof turkish efl student teachers? Mediterrenean Journal of Educational Studies, 13(1), $1-24$.

Koszalka, T. (2001). KaAMS: A PBL Environment Facilitating Reflective Thinking. Learning and Instruction Section. NY.

Lim, L. Y. (2011). A Comparison of Students' Reflective Thinking Across Different Years in A Problem-Based Learning Environment. Journal of Instructional Science, 39(2), 171-188. https:/ / doi.org/10.1007/s11251-009-91238

Lipman, M. (2003). Thinking in Education. Cambridge: Cambridge University Press. https://doi.org/10.1017/CBO9780511840272

Mbulu, J. and Suhartono. (2004). Pengembangan Bahan Ajar. Malang: Elang Mas.

Mulyasa, E. (2007). Kurikulum Tingkat Satuan Pendidikan. Bandung. Remaja Rosdakarya.

Prastowo, A. (2012). Panduan Kreatif Membuat Bahan Ajar Inovatif. Yogyakarta: Diva Press. 